\title{
Resler M. ACCOUNTING AND ANALYTICAL SUPPORT OF THE MARKETING OF THE COMMISSION OPERATION OF THE TRADE ENTERPRISES
}

Об’єктом дослідження є комісійні операщї підприємств торгівлі. Під час дослідження наукових праць вчених-економістів, присвячених проблемам обліково-аналітичного забезпечення маркетингу комісійними операціями підприємств торгівлі використовувались методи аналізу та синтезу. А для визначення галузевих проблем обліку та аналізу витрат використовувались методи індукції та дедукції. Також у ході дослідження використовувались методи порівняння та аналогї при аналізі досвіду ведення обліку і аналізу витрат та маркетингових ризиків. А в процесі аналізу порядку формування обліково-аналітичної системи підприємств застосовувались методи абстрагування та конкретизачії. Теоретичне же дослідження застосовувалось в процесі поглиблення трактування сутності термінів «торгівля» та «комісійна торгівля». Потрібно відмітити, що запропонований у роботі підхід має ряд особливостей щодо обліково-аналітичного забезпечення управління маркетинговими комісійними операщіями підприємств торгівлі. Такий підхід необхідно розглядати як підсистеми обліку та аналізу. Це пов'язано з тим, що запропонований у роботі розподіл дає можливість уникнути ризиків під час торгівельної діяльності. Саме підсистеми обліку і аналізу дають повну обліково-аналітичну інформацію. Показано, що важливим моментом в торгівельній діяльності є врахування думки споживачів. Автор роботи погоджується з думкою науковців, які пропонують враховувати корпоративну інформацію і все більше усвідомлюють, якою мірою функціональні сфери діяльності з маркетингу та ланцюга поставок стають все більш інтегрованими. Показано, що функціональна інтеграція передбачає координацію діяльності, орієнтованої на попит та пропозицію, і теоретично передбачає створення двох взаємопов'язаних переваг для споживачів: зниження маркетингового ризику купівлі та, в кінцевому рахунку, більш високого рівня споживчої марки. Завдяки цьому забезпечується можливість отримання необхідної інформацї̈ для обліково-аналітичного забезпечення маркетингу комісійними операціями торгівельної діяльності.

Ключові слова: обліково-аналітичне забезпечення, комісійні операчї, маркетинговий ризик, підприємства торгівлі.

Received date: 28.11 .2018

Accepted date: 18.12 .2018

Published date: 30.06 .2019
Copyright (C) 2019, Resler M. This is an open access article under the CC BY license (http://creativecommons.org/licenses/by/4.0)

\section{Introduction}

The qualitative characteristics of the market environment are influenced by information technologies, namely, accounting and analytical support in the direct sense of the word provides prompt information to trade enterprises with full characteristics of the market environment. An integral element of the assessment of market conditions when conducting marketing research arise marketing risks. Therefore, marketing risks affect the formation of accounting and analytical information, in turn, correctly and effectively optimize the costs of a commercial enterprise.

Accounting and analytical support costs studied in [1,2]. The study of the theory of accounting and control of marketing costs involved the authors of works [3-5]. The study of risks is devoted to the work [6-8]. In many works of scientists the low-level aspects of the formation and use of accounting information of marketing risk management in trade are revealed. However, the problem of managing accounting and analytical marketing support for commission operations of trade enterprises remains highly relevant. Therefore, the object of research is commission operations of trade enterprises. And the aim of research is minimization of marketing risks in the implementation of commission transactions in trade. So, as accounting and analytical support plays an important management function associated with the identification of risks in the implementation of trading activities.

\section{Methods of research}

The methods are used:

- analysis and synthesis - in the study of scientific works of economists on the problems of accounting and analytical support;

- induction and deduction - to identify industry problems of accounting and cost analysis;

- comparisons and analogies - when analyzing the experience of keeping records and analyzing costs and marketing risks;

- abstraction and specification - in the process of analyzing the order of formation of the accounting and analytical system of enterprises;

- theoretical research - in the process of deepening the interpretation of the essence of the terms «trade» and «commission trade». 


\section{Research results and discussion}

To successfully solve the problem of marketing risk management, first of all it is necessary to clarify the essence of the concept of «marketing risks». Analyzing various points of view of specialists, it is possible to note that there are disagreements in their views, and let's conditionally divide into three groups.

The first group includes authors who consider marketing risks from the perspective of the risks of a particular investment project, they actually identify them with the commercial or marketing risks of its implementation. For example, «marketing risk is the risk of shortfall in profits as a result of a decrease in the volume or price of a product» [6].

The second group of views includes specialists who are engaged in the economy of agriculture. They take into account the fact that «marketing is that part of the business that turns the production results of activities into financial ones» [3]. According to this view, «marketing risks include any activity or event that can lead to fluctuations and unpredictability of prices for both farm products and the factors of production that they use» [4].

The third group includes the group of authors whose views on marketing risks are due to the fact that in one way or another they associate them with the marketing function of the enterprise. «Marketing risks arise in the process of selling goods, as a result of the action of many factors caused by the market situation, the situation in the enterprise itself, as well as errors in marketing planning, organization and implementation of marketing activities» [7].

Commercial activity in our time has undergone significant transformational changes, in particular, not only in the expansion of the components that form such a sphere of management, but also in the ways and forms of its implementation. Of particular importance is such a form of activity as commission trading. That is, commission trading is a prime example of mediation. And in the everyday consciousness of citizens, commission trade is the sale of second-hand goods.

Exploring this issue, it is possible to note some authors who in their works examine the term - commission trading.

Thus, the author of [9] notes that «commission trading is a type of trade in which goods that were in use are sold (or at least once sold to a consumer)».

The author of the work [10] defines that «commission trading is a form of trade in which trade organizations or enterprises assume the intermediary function of selling goods or property and other valuables for a corresponding fee on behalf of individuals or legal entities».

The author of the work [11] understands commission trade as «a special type of trading activity, which is that a trade enterprise sells goods that are not its property, but belong to another enterprise or an individual».

Analyzing the definitions, it should be noted that in their writings some scientists identify the concept of commission trading with intermediary trade. Agreeing with the opinion of the author of the work [12], such a combination is not appropriate, since commission trading is one of the components of intermediary operations and has its own differences and specific features (Table 1).

Taking into account the information that is presented in the Table 1, it is possible to note that it is impossible to identify two such concepts as commission trading and intermediary trading. Since these two categories, as for restrictions on trade, property rights, definition of income and regulations have their limitations in the implementation of trading activities. It should also be noted that the accounting and analytical support for managing marketing commission operations of trade enterprises should be considered as subsystems of accounting and analysis (Table 2).

Table 1

The matrix of common and distinctive features in terms of: trade and commission trading

\begin{tabular}{|c|l|c|c|}
\hline \multirow{2}{*}{ No. } & \multicolumn{2}{|c|}{ Feature } & \multicolumn{2}{c|}{ Compare concepts } \\
\cline { 3 - 4 } & & Trade & Commission trade \\
\hline 1 & Mediation contact & - & - \\
\hline 2 & Costs associated with trading activities & + & + \\
\hline 3 & Restrictions on trading activities & - & - \\
\hline 4 & Property rights & - & - \\
\hline 5 & Revenue recognition & - & - \\
\hline 6 & Network availability & + & + \\
\hline 7 & Indicator characterizing trading activity & + & + \\
\hline 8 & Regulatory & - & - \\
\hline
\end{tabular}

Table 2

Components of the system of accounting and analytical support for marketing management of commission operations of trade enterprises

Accounting and analytical support of marketing management to commission operations of a trade enterprise

\begin{tabular}{|l|l}
\hline Accounting subsystem & Analysis subsystem \\
\hline
\end{tabular}

Operational technical ac- Recognition of possible items of expenditure counting of the sale of and analysis of the distribution of financial regoods sources

\begin{tabular}{|l|l|}
\hline Management accounting & $\begin{array}{l}\text { Comparison of revenues from sales and gross } \\
\text { profit with current costs }\end{array}$ \\
\hline Financial accounting & Functional cost analysis \\
\hline Strategic accounting & $\begin{array}{l}\text { Distribution of functional costs according to the } \\
\text { marketing classification: } \\
\text { - individual product groups; } \\
\text { - methods and forms of implementation; } \\
\text { - market segments }\end{array}$ \\
\hline Strategic analysis & $\begin{array}{l}\text { Analysis of the effectiveness of marketing acti- } \\
\text { vities: } \\
\text { - evaluation of product groups; } \\
\text { - implementation methods; } \\
\text { - members of sales channels; } \\
\text { - sales staff; } \\
\text { - promotional activities }\end{array}$
\end{tabular}

The formation of accounting and analytical marketing support for commission operations of trade enterprises depends on significant factors affecting this type of activity. Therefore, the formation of accounting and analytical information on marketing activities should take into account marketing risks (Fig. 1).

This impact of marketing risks is ahead of the submission of false information, which relates directly to commission operations and, in general, to the activities of trade enterprises. 


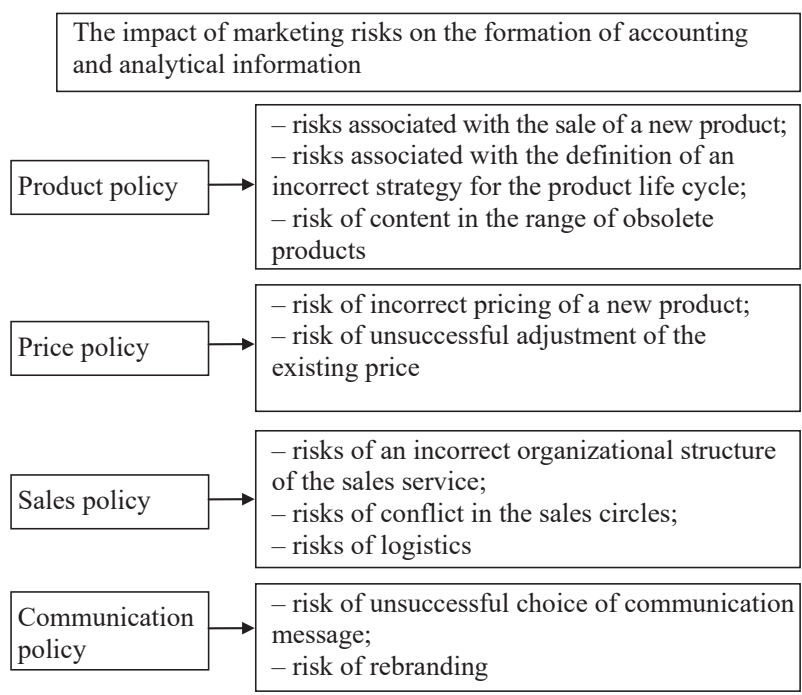

Fig. 1. The impact of marketing risks on the formation of accounting and analytical information

It should also be noted that in the economic life of trade enterprises risks are combined in a single chain. Therefore, minimizing risks and making management decisions on accounting for commission operations can be accomplished by diversifying production and sales, careful selection of areas and activities. So as to maximize the opportunities and minimize the impact of destructive factors. However, if in order to reduce the level of marketing risks of an enterprise, the factors of macroenvironment can only be taken into account, but not influenced by them, then at the micro level there are much more opportunities for influence.

\section{Conclusions}

The proposed approach has a number of peculiarities in accounting and analytical support for managing marketing commission operations of trade enterprises. This approach should be considered as accounting and analysis subsystems. This is due to the fact that the distribution proposed in the work makes it possible to avoid risks in trading activities. It is the accounting and analysis sub- systems that provide complete accounting and analytical information.

The data in the course of the research offers in further studies to improve the methodological approaches to the accounting display of measures to minimize the negative consequences of risks and the formation of information support for the analysis of business risks.

\section{References}

1. Kutsyk P. O. Orhanizatsiino-ekonomichnyi mekhanizm upravlinnia efektyvnistiu diialnosti pidpryiemstv spozhyvchoi kooperatsii Ukrainy: monograph. Poltava: RVV PUSKU, 2008. P. 96-102.

2. Maksymenko D. V. Oblikovo-analitychne zabezpechennia stratehichnoho analizu // Visnyk Natsionalnoho universytetu «Lvivska politekhnika». Menedzhment ta pidpryiemnytstvo v ukraini: etapy stanovlennia i problemy rozvytku. 2012. Issue 722 . P. $150-154$

3. Risk Management Agency (RMA) // United States Department of Agriculture (USDA). URL: http://www.rma.usda.gov

4. ASU Extension // Alcorn State University. URL: https:// www.alcorn.edu/academics/schools-and-departments/school-ofagriculture-and-applied-sciences/land-grant-programs/extensionand-outreach

5. Chambers R. J. Accounting and Analytical Methods: A Review Article // Journal of Accounting Research. 1966. Vol. 4, Issue 1. P. 101-118. doi: http://doi.org/10.2307/2490144

6. Korol S. V., Dorozhkin A. V. Otsenka riska investitsionnykh proektov // Imushchestvennye otnosheniia v Rossiiskoi Federatsii. 2005. Issue 11 (50). P. 86-93.

7. Kidon V. Net kommertsii bez riska // Apteka. 2000. Issue 9 (230). URL: https://www.apteka.ua/article/10497

8. Kirchoff J. F., Nichols B. S., Rowe W. J. The impact of functional integration on perceived risk and consumer-based brand equity // Journal of Strategic Marketing. 2017. Vol. 27, Issue 2. P. 136-150. doi: http://doi.org/10.1080/0965254x.2017.1384746

9. Mochernyi S. V. Ekonomichnyi entsyklopedychnyi slovnyk. Kyiv: Vydavnychyi tsentr «Akademiia, 2002. 530 p.

10. Andriushchenko V. A., Lusta I. S. Prava spozhyvachiv v Ukraini. 1999. URL: http://yport.inf.ua/prava-potrebiteley-ukraine.html

11. Atamas P. Y. Bukhhalterskyi oblik u haluziakh ekonomiky: textbook. Kyiv: Tsentr uchbovoi literatury, 2008. 392 p.

12. Drozdova O. H. Komisiina torhivlia - spetsyfichna forma torhovelnoi diialnosti // Visnyk sotsialno-ekonomichnykh doslidzhen. 2014. Issue 2 (53). P. 56-60.

Resler Maryna, Doctor of Economic Sciences, Professor, Head of Department of Accounting, Taxation and Marketing, Mukachevo State University,Ukraine, e-mail: reslermarina76@gmail.com, ORCID: http://orcid.org/0000-0002-3787-9472 